\title{
Influence of elevated ozone concentration on methanotrophic bacterial communities in soil under field condition
}

\author{
Y.Z. Huang ${ }^{a,}{ }^{*}$, M. Zhong ${ }^{b}$ \\ ${ }^{a}$ Agro-Environmental Protection Institute, Ministry of Agriculture, Tianjin 300191, China \\ b Department of Soil Sciences, Research Center for Eco-Environmental Sciences, Chinese Academy of Sciences, Beijing 100085, China
}

\section{H I G H L I G H T S}

- $\mathrm{O}_{3}$ stress can influence the potential methane oxidation rate (PMOR).

- $\mathrm{O}_{3}$ influenced the potential methane production rate (PMPR) in soil.

- $\mathrm{O}_{3}$ and the soil depth affected the gene pmoA of total methanotrophic bacteria.

- $\mathrm{O}_{3}$ and the soil depth affected the type I and type II methanotrophic bacteria.

- $\mathrm{O}_{3}$ influenced the community structure of the methanotrophic bacteria in soil.

\section{A R T I C L E I N F O}

\section{Article history:}

Received 17 November 2014

Received in revised form 10 February 2015

Accepted 26 February 2015

Available online 28 February 2015

\section{Keywords:}

Community

Methanotrophic bacteria

Ozone

Real-time quantitative PCR

Soil

T-RLFP

Winter wheat

\begin{abstract}
A B S T R A C T
The open top chamber (OTC) method was used in combination with real-time quantitative PCR and terminal restriction fragment length polymorphism (T-RFLP) techniques in the wheat field to study the influence of different levels of $\mathrm{O}_{3}$ concentrations (ambient air filtered by activated carbons, $40 \mathrm{ppb}$, $80 \mathrm{ppb}$ and $120 \mathrm{ppb}$ ) on the quantity and community structure of methanotrophic bacteria. $\mathrm{O}_{3}$ stress can influence the potential methane oxidation rate (PMOR) and potential methane production rate (PMPR) in the farmland soil. $\mathrm{O}_{3}$ treatment of $40 \mathrm{ppb}$ improved significantly the 16S rRNA gene copy number in the total methanotrophic bacteria $p m o A$, and type I and type II methanotrophic bacteria in the soil depth of 0 $-20 \mathrm{~cm}$. When the $\mathrm{O}_{3}$ concentration reached $120 \mathrm{ppb}$, the $16 \mathrm{~S}$ rRNA gene copy number in the total methanotrophic bacteria $p m o A$ and type I methanotrophic bacteria decreased significantly as compared to the control treatment in 10-20 cm layer. The 16s rRNA gene copy number of total methanotrophic bacteria $p m o A$ and type I and type II methanotrophic bacteria were influenced by different $\mathrm{O}_{3}$ concentration and soil depth. The T-RFLP analysis indicated that $\mathrm{O}_{3}$ stress influenced significantly the community structure of the methanotrophic bacteria in soil, causing potential threat to the diversity of methanotrophic bacteria. It seems to imply that the rise of $\mathrm{O}_{3}$ concentration could produce an impact on the carbon cycling and the methane emission of the wheat field soil by changing the community structure and diversity of methanotrophic bacteria, which then influences the global climate change.
\end{abstract}

() 2015 Elsevier Ltd. All rights reserved.

\section{Introduction}

Methane is an important greenhouse gas, with a contribution of about $25 \%$ to the global warming (Thompson et al., 1992). The methane concentration in the global atmosphere has increased from $715 \mathrm{ppb}$ before the industrialization to the present $1800 \mathrm{ppb}$ (Shindell et al., 2009). The microbes are involved in the methane

\footnotetext{
* Corresponding author.

E-mail address: hyz@rcees.ac.cn (Y.Z. Huang).
}

cycling in two ways, methanogenesis and methane oxidation (Edwards et al., 1998; Raghoebarsing et al., 2005). In natural soil, methanogens and other bacteria form a special syntrophism, by which the biomass is continuously degraded and the terminal electrons are accepted to produce methane. A large part of the methane is oxidized by the methanotrophic bacteria before being released to the atmosphere from soil and water (Le Mer and Roger, 2001).

Methanotrophic bacteria are a group of microbes that rely on methane as the sole carbon source and energy. It oxidizes methane into methanol under the action of methane monooxygenase 
(MMO), and the latter is subsequently oxidized into formaldehyde by methanoldehydrogenase (MDH). Formaldehyde is oxidized into formic acid by formaldehyde dehydrogenase (FADH), and under the effects of formate dehydrogenase (FDH), formic acid is oxidized into $\mathrm{CO}_{2}$ (Hanson and Hanson, 1996; Madigan et al., 2009). The methanotrophic bacteria that participate in this oxidation process are divided into three types: type I, type II and type X methanotrophic bacteria (Hanson and Hanson, 1996). The methane consumed by the oxidation by methanotrophic bacteria in the soil takes up approximately $10 \%$ of the total methane consumption in the atmosphere (Duxbury and Mosier, 1993). Therefore, the methanotrophic bacteria play a crucial role in the carbon cycling of terrestrial ecosystems and in the global atmospheric methane balance (Duxbury and Mosier, 1993).

In the molecular ecological studies of methanotrophic bacteria, the available target genes include the 16S rRNA gene and some functional genes encoding the important enzymes involved in the methane oxidation (Zheng, 2009). Gene pmoA, which encodes particulate methane monooxygenase (pMMO), can be used to detect all the methanotrophic bacteria other than Methylocella; gene $m m o X$ specifically encodes soluble methane monooxygenase (sMMO); gene $m x a F$ is the gene encoding methanol dehydrogenase present in most Gram-negative methylotrophic bacteria. The 16S rRNA gene can be used to distinguish type I from type II methanotrophic bacteria.

Due to rapid population growth, economic development and energy demand, people have to recklessly exploit and utilize fossil fuels and nitrogen fertilizers, which increases the $\mathrm{O}_{3}$ concentration in the surface layer. The surface $\mathrm{O}_{3}$ pollution has become one of the most challenging environmental issues (Selin et al., 2009). The average $\mathrm{O}_{3}$ concentration in the troposphere rose from $38 \mathrm{ppb}$ before the industrial revolution to $50 \mathrm{ppb}$ in 2000. It is predicted that by 2050 , the average $\mathrm{O}_{3}$ concentration in the surface layer will be as high as $70 \mathrm{ppb}$, and will reach $80 \mathrm{ppb}$ by 2100 , much higher than $40 \mathrm{ppb}$, which is the critical value of damage to plants (Fiscus et al., 2005; Sitch et al., 2007). In the Yangtze River Delta region and Beijing, the maximum surface $\mathrm{O}_{3}$ concentration has reached over 150 ppb (Shao et al., 2006; Zhang, 2010).

The $\mathrm{O}_{3}$ pollution has damaging effects to plants (Avnery et al., 2013), causing the reduction of crop yield and huge economic loss (Feng et al., 2003; Zhu et al., 2011). The influence of $\mathrm{O}_{3}$ stress on terrestrial ecosystems is not limited to the aboveground part. $\mathrm{O}_{3}$ stress also affects the reactions and underground carbon cycling. It is reported that the rise of atmospheric $\mathrm{O}_{3}$ concentration inhibits the growth of plant roots, reduces the root biomass and the microbial activity (Kasurinen et al., 2005; Chen et al., 2009). Reddy et al. (1995) studied the impact of $\mathrm{O}_{3}$ stress on the soil enzymes of Pinus taeda. They found that when the $\mathrm{O}_{3}$ concentration was $160 \mathrm{ppb}$, it inhibited significantly the activity of the phosphatase in the soil; when the concentration reached $240 \mathrm{ppb}$, it significantly inhibited the activity of soil arylsulfatase. The high $\mathrm{O}_{3}$ concentration reduced significantly the microbial biomass carbon in the farmland soil, but had little influence on the soil organic carbon content (Islam et al., 2000).

Recently, it was found that the $\mathrm{O}_{3}$ stress reduced significantly the methane emission in the farmland soil (Bhatia et al., 2011; Zheng et al., 2011), however the microbial mechanics that regulates the soil methane emission under $\mathrm{O}_{3}$ stress has not been reported. Our hypothesis is that the $\mathrm{O}_{3}$ stress influences the soil methane emission by exerting impact on the structure and functions of the microbial communities that participate in the soil carbon cycling in the farmland (such as methanotrophic bacteria). This study investigated the influence of $\mathrm{O}_{3}$ concentration increase on the structure and functions of soil methanotrophic bacteria by the open top chamber (OTC) method in the winter wheat field. The molecular biotechnologies such as real-time quantitative PCR and T-RLFP were used to reveal the changing characteristics of the soil methanotrophic bacteria and the mechanism driving the dynamics of the methane emission by microbes under the $\mathrm{O}_{3}$ stress in the field.

\section{Materials and methods}

\subsection{Experiment site}

The experiment site was located in the Seed Management Station of Changping, Beijing $\left(40^{\circ} 12^{\prime} \mathrm{N}, 116^{\circ} 8^{\prime} \mathrm{E}\right)$. The station is located in the northwest Beijing with continental monsoon climate and four distinct seasons. The annual average rainfall is $550.3 \mathrm{~mm}$. The annual average temperature is $11.8{ }^{\circ} \mathrm{C}$. The fundamental physicochemical properties of soil are as follows: organic matter contents $16.4 \mathrm{~g} \mathrm{~kg}^{-1}$; total nitrogen $0.9 \mathrm{~g} \mathrm{~kg}^{-1}$; available phosphorus $38.1 \mathrm{mg} \mathrm{kg}^{-1}$; available potassium $102.1 \mathrm{mg} \mathrm{kg}{ }^{-1}$; $\mathrm{pH}$ value 8.3 .

\subsection{Plant material}

The variety used in the experiment was Triticum aestivum $\mathrm{L}$. Beinong 9549, provided by Beijing Agriculture College. The seeds were sowed on September 28, 2009. Before sowing, the compost was applied. On April 26, 2010, urea was applied (225 kg ha ${ }^{-1}$ ). The field management was coherent to that of the local farms during the entire growth season of winter wheat.

\subsection{Ozone fumigation}

In-situ ozone fumigation experiment was carried out on winter wheat with the self-made open-top fumigation system (Fig. 1, Huang et al., 2012). Four $\mathrm{O}_{3}$ treatments were set up: the ambient air filtered by activated carbon (CK), $40 \mathrm{ppb}, 80 \mathrm{ppb}$ and $120 \mathrm{ppb} .3$ replicates were set for each treatment. $\mathrm{O}_{3}$ fumigation on winter wheat began from April 5, 2010. The fumigation lasted for $9 \mathrm{~h}$ (8:00-17:00) every day and stopped on June 12 . The duration was 50 days. On June 13, 2010 (during the grain-filling stage of the winter wheat), the soil samples were collected. The 5-point mixing method was used for sampling. In every experimental plot, the fresh soil at the depths of $0-10,10-20$ and $20-40 \mathrm{~cm}$ was collected respectively with an earth auger $2 \mathrm{~cm}$ in diameter. The gravels and root residues were removed. The samples were mixed separately, put into sterile sampling bags for cold storage and taken back to the laboratory. The samples were sieved through the filter of $2.0 \mathrm{~mm}$. Part of the soil samples were preserved in refrigerator at $-80{ }^{\circ} \mathrm{C}$ and $4{ }^{\circ} \mathrm{C}$. The test of soil properties and total DNA extraction were conducted. The remaining soil samples were freeze dried and

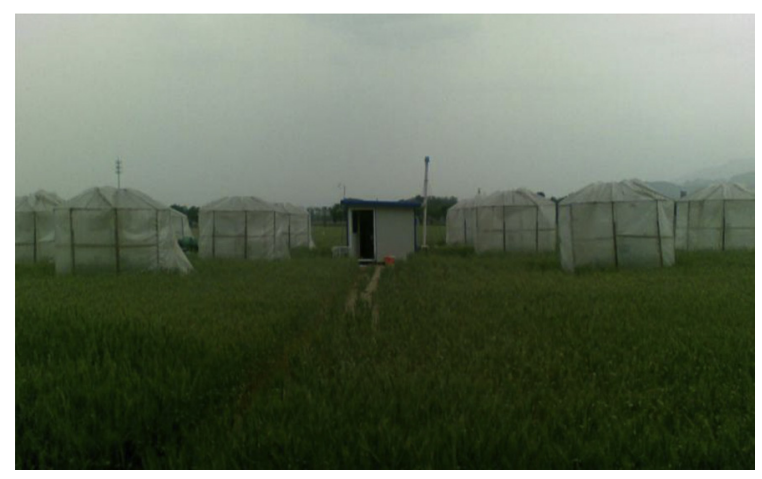

Fig. 1. Simulation experiment of ozone stress on winter wheat grown in the field. 
sieved through the filter of $1.0 \mathrm{~mm}$, for the determination of basic soil physical and chemical properties and nutrient contents.

\subsection{Potential methane oxidation rate (PMOR) and potential methane production rate (PMPR) analysis}

The PMOR was measured by reference to the method of McDonald et al. (1996), and the PMPR analysis referenced to the method of Wang et al. (2007). The PMOR and PMPR were both expressed as $\mu \mathrm{g} \mathrm{g}^{-1} \mathrm{~h}^{-1}$.

\subsection{DNA extraction}

DNA was extracted from $0.5 \mathrm{~g}$ fresh soil using the FastDNA SPIN Kit (Bio 101, Inc., USA) following the manufacturer's instructions. Extracted DNA was separated on a 1\% agarose gel. The concentration was determined using a ND-1000 Spectrophotometer (Nanodrop Technologies, Wilmington, DE), and DNA was stored at $-20^{\circ} \mathrm{C}$ before use.

\subsection{Quantitative analysis of the methanotrophs by real-time PCR}

The functional gene $p m o A$ was chosen as the target gene to quantify methanotrophic bacteria. The specific primers of the $16 \mathrm{~S}$ rRNA gene in methanotrophic bacteria were selected to distinguish between type I and type II methanotrophic bacteria. The primers A189 (Bodrossy et al., 1997)/mb661 (Knief et al., 2006) were used to quantify the $p m o A$ gene copy number in the total methanotrophic bacteria. The primers MB10 $\gamma / 533 r$ and $\mathrm{MB} 9 \alpha / 533 \mathrm{r}$ were used to quantify the 16S rRNA gene copy number of type I and type II methanotrophic bacteria (Henckel et al., 1999; Bodelier et al., 2000). The primer sequences are shown in Table 1 . The reaction concentration was $200 \mathrm{nM}$. The PCR primers were synthesized by Invitrogen, Life Technologies, Beijing, China. For all the PCR reactions, the SYBR ${ }^{R}$ Premix Ex TaqTM (TaKaRa, Biotechnology) tool kit was used. The $0.4 \mathrm{mg} \mathrm{ml}^{-1}$ bovine serum albumin (BSA) and $1 \mu \mathrm{l}$ DNA templates were added to the reactions. The quantitative PCR apparatus was iCycler iQ5 (Bio-Rad, USA). The reaction procedures are shown in Table 1. The data analysis was performed by iCycler (version 1.0.1384.0 CR). The clones of the tested soil samples were adopted for the quantification of the $p m o A$ gene of total methanotrophic bacteria and the 16S rRNA genes of type I and type II methanotrophic bacteria.

\section{7. pmoA-based T-RFLP analysis}

The primers used were A189 (Bodrossy et al., 1997) and mb661 (Knief et al., 2006). Their sequences are listed in Table 1 . The $5^{\prime}$ end of the forward primer was labeled with fluorescent dye 6carboxyfluorescein (6-FAM). The PCR reaction system was $50 \mu \mathrm{L}$, including $5 \mu \mathrm{l} 10 \times$ PCR Ex buffer ( $\mathrm{Mg}^{2+}$ plus), $4 \mu \mathrm{l} 2.5 \mathrm{mM}$ dNTPs,

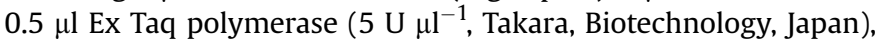
$1 \mu \mathrm{l}$ of forward and backward primers, respectively, $1 \mu \mathrm{l}$ BSA $\left(20 \mathrm{mg} \mathrm{mL}^{-1}\right), 2 \mu \mathrm{l}$ DNA template $\left(\sim 10 \mathrm{ng} \mu \mathrm{l}^{-1}\right)$, sterilized doubledistilled water $35.5 \mu$ l. The amplification reaction was conducted in eppendorf thermocycler. The procedures were 5 min of predegeneration at $95{ }^{\circ} \mathrm{C}$; 10 cycles of "Touchdown" procedure; degeneration at $94{ }^{\circ} \mathrm{C}$ for $45 \mathrm{~s}$; the renaturation temperature started from $62{ }^{\circ} \mathrm{C}$; after each thermal cycle, the temperature was lowered by $1.0^{\circ} \mathrm{C}$ until $52^{\circ} \mathrm{C}$; the renaturation duration was $1 \mathrm{~min}$; the extension was conducted at $72{ }^{\circ} \mathrm{C}$ for $1 \mathrm{~min}$. After the "Touchdown" procedure, 30 cycles of isothermal amplification were conducted. The renaturation temperature was $56{ }^{\circ} \mathrm{C}$. With other conditions constant, the extension was conducted again for $10 \mathrm{~min}$.

The PCR purity and yield were tested by $1 \%$ agarose gel electrophoresis. The $p m o A$ gene fragments were purified by gel slice with Wizard SV Gel and PCR Clean-Up System (Promega, USA). The procedures were referred to the instruction. Finally, the products were dissolved in $40 \mu \mathrm{l}$ sterilized deionized water. The restriction endonuclease Msp I was used for the enzyme digestion of the PCR products. The reaction lasted for $6 \mathrm{~h}$ at $37^{\circ} \mathrm{C}$; then denaturation was conducted at $95{ }^{\circ} \mathrm{C}$ for $3 \mathrm{~min}$. The products were cooled on ice immediately. Genescan was conducted on the enzyme digestion products after purification with the 3130xl Genetic Analyzer (Applied Biosystems, USA). The T-RFLP analysis was conducted by using GeneMapper (Applied Biosystems, USA). According to the detection range of the standard sample GeneScan ${ }^{\mathrm{TM}} 1000 \mathrm{ROX}^{\mathrm{TM}}$ Size Standard (Applied Biosystems), the fragments with length less than 500 bp were selected for the analysis. The ratio of every peak height to the total peak height was calculated. The peak with a height ratio less than $0.05 \%$ was not included in the data analysis.

\subsection{Cloning and sequencing}

The primers used in the establishment of cloning library were the same as those in the real-time fluorescence quantitative PCR. The PCR system and procedures were the same as those of the PCR reactions in the T-RFLP analysis. The total soil DNA of the four duplicates of every treatment was mixed and then used as the templates for PCR amplification. The purity and yield of the products were determined with $1 \%$ agarose gel electrophoresis. The pmoA and mcrA gene fragments obtained from PCR were purified by Wizard SV Gel and PCR Clean-Up System (Promega, USA). The procedures were conducted by following the instruction of the toolkit. Then, the product was eluted with $50 \mu \mathrm{l}$ sterilized water. The purified DNA fragments were connected to the vector by pGEM-T Easy toolkit (Promega, Corp., Madison, Wis., USA) and then transferred to the competent Escherichia coli cells (JM109) (TaKaRa), which were coated in the LB (Luria-Bertani) media containing Ampicillin/IPTG/X-Gal for culture at $37{ }^{\circ} \mathrm{C}$ for $16-24 \mathrm{~h}$. A certain amount of white clones were selected randomly. With direct amplification, the exogenous fragments were amplified with the primer T7/SP6 of pGEM-T Easy Vector. The clones carrying the inserted fragments were tested with electrophoresis. The corresponding clone liquid was sequenced.

\subsection{Phylogenetic analysis}

The sequencing analysis of the target gene fragments was

Table 1

PCR primers used in this study.

\begin{tabular}{|c|c|c|c|c|}
\hline Target gene & Primer set & Sequence $\left(5^{\prime}-3^{\prime}\right)$ & Thermal profile & Reference \\
\hline pmoA & $\begin{array}{l}\text { A189 } \\
\text { mb661 }\end{array}$ & $\begin{array}{l}\text { GGNGACTGGGACTTCTGG } \\
\text { CCGGMGCAACGTCYTTACC }\end{array}$ & $\begin{array}{l}95^{\circ} \mathrm{C} \text { for } 2 \mathrm{~min} \text { followed by } 40 \text { cycles of } 1 \mathrm{~min} \text { at } 94{ }^{\circ} \mathrm{C} \text {, } \\
1 \mathrm{~min} \text { at } 56^{\circ} \mathrm{C} \text { and } 45 \mathrm{~s} \text { at } 72{ }^{\circ} \mathrm{C} \text {, plate read at } 83^{\circ} \mathrm{C}\end{array}$ & Bodrossy et al., 1997; Knief et al., 2006 \\
\hline 16S rRNA-Type I & $\begin{array}{l}\text { MB10 } 10 \\
533 r\end{array}$ & $\begin{array}{l}\text { AAGCGGGGGATCTTCGGACC } \\
\text { TTACCGCGGCTGCTGGCAC }\end{array}$ & $\begin{array}{l}95^{\circ} \mathrm{C} \text { for } 2 \mathrm{~min} \text { followed by } 36 \text { cycles of } 1 \mathrm{~min} \text { at } 95^{\circ} \mathrm{C} \text {, } \\
1 \mathrm{~min} \text { at } 60^{\circ} \mathrm{C} \text {, plate read at } 83^{\circ} \mathrm{C} \mathrm{s}\end{array}$ & Henckel et al., 1999; Bodelier et al., 2000 \\
\hline 16S rRNA-Type II & $\begin{array}{l}\text { MB9 } \alpha \\
533 r\end{array}$ & $\begin{array}{l}\text { GTTCGGAATAACTCAGGG } \\
\text { TTACCGCGGCTGCTGGCAC }\end{array}$ & $\begin{array}{l}95^{\circ} \mathrm{C} \text { for } 2 \text { min followed by } 36 \text { cycles of } 1 \text { min at } 95^{\circ} \mathrm{C} \text {, } \\
1 \text { min at } 60^{\circ} \mathrm{C} \text {, plate read at } 83^{\circ} \mathrm{C}\end{array}$ & Henckel et al., 1999; Bodelier et al., 2000 \\
\hline
\end{tabular}


performed by using DNAStar and DNAMAN version 4.0. Then the sequence with the right length was submitted to the NCBI database (http://www.ncbi.nlm.nih.gov/). It was compared with the sequences in the database with the Blast method. The sequence with the highest similarity was downloaded as the reference sequence of the phylogenetic tree. The multiple sequence comparison was conducted with the ClustalW alignment method in MEGA 4.0. The neighbor joining method was used for the phylogenetic analysis. The confidence level of the branches of the phylogenetic tree was tested with Bootstrap analysis. The test was repeated for 1000 times. The obtained sequences were submitted to the GenBank database under accession numbers KF015205-KF015221.

\subsection{Diversity indices}

The Shannon diversity index $\mathrm{H}$ and Evenness index E were used to calculate the band pattern diversity of methanotrophs based on the following equations:

$\mathrm{H}=-\sum \mathrm{p}_{i} \ln \mathrm{p}_{i}=-\sum\left(\mathrm{N}_{i} / \mathrm{N}\right) \ln \left(\mathrm{N}_{i} / \mathrm{N}\right)$

$\mathrm{E}=\mathrm{H} / \mathrm{H}_{\max }=\mathrm{H} / \ln S$

where $\mathrm{N}_{i}$ is the abundance of the $i$ th ribotype, $\mathrm{N}$ is the total abundance of all ribotypes in the sample (lane of T-RF gels) and $\mathrm{S}$ is the number of ribotypes.

\subsection{Statistical analysis}

The copy number obtained in the quantitative test was statistically analyzed after the logarithmic conversion. The Ducan's test of the one-way ANOVA in SPSS 16.0 was used to calculate the significant difference $(p<0.05)$. The correlation was analyzed with the Correlation-Bivariate; multivariate ANOVA was conducted to determine the influence level of the environmental factors. CANOCO for Windows 4.5 was used for the T-RFLP analysis.

\section{Results}

\subsection{Effects of $\mathrm{O}_{3}$ on methnotrophic communities in soil}

Compared with the control treatment, the PMORs of $0-10 \mathrm{~cm}$ and $10-20 \mathrm{~cm}$ layers were both decreased under $\mathrm{O}_{3}$ stress (Fig. 2). When $\mathrm{O}_{3}$ concentration was over $80 \mathrm{ppb}$, the PMOR of $0-10 \mathrm{~cm}$ layer was also decreased significantly as compared to the CK treatment $(\mathrm{P}<0.05)$. There was not significant difference of PMOR of $20-40 \mathrm{~cm}$ layer between all treatments.

The PMPR of $0-10 \mathrm{~cm}$ layer was higher than the control treatment under $\mathrm{O}_{3}$ stress (Fig. 2). At the $\mathrm{O}_{3}$ concentration of $40 \mathrm{ppb}$, the PMPR reached the maximum $\left(0.15 \mu \mathrm{g} \mathrm{CH}_{4} \mathrm{~h}^{-1} \mathrm{~g}^{-1}\right.$ dry soil). There was not significantly different PMPR of $0-10 \mathrm{~cm}$ layer between treatments. The similar changing tendency of PMPR of $10-20 \mathrm{~cm}$ layer was showed in Fig. 2. There was significant difference of PMPR of $10-20 \mathrm{~cm}$ layer between $\mathrm{O}_{3}$ stress and control treatment $(P<0.05)$. The PMPR of $20-40 \mathrm{~cm}$ layer was not significantly different under every $\mathrm{O}_{3}$ concentration. With the increase of $\mathrm{O}_{3}$ concentration, the PMPR of $20-40 \mathrm{~cm}$ layer decreased.

\subsection{Effects of $\mathrm{O}_{3}$ on methanotrophic abundance indicated by type I and II}

Compared with the control, the 16S rRNA gene numbers of type I methanotrophic bacteria in the three depths of winter wheat field soil were increased significantly under low (40 ppb) and medium

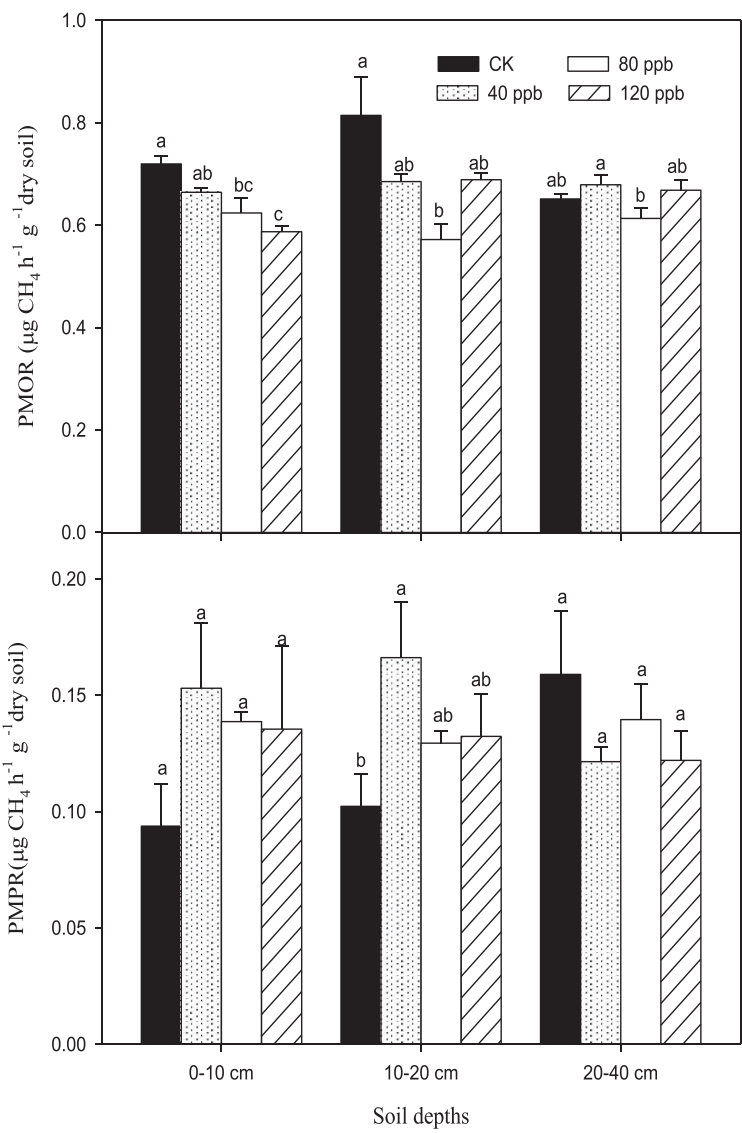

Fig. 2. Effect of ozone on potential methane oxidation rate (PMOR) and potential methane production rate (PMPR) in winter wheat field soil.

(80 ppb) $\mathrm{O}_{3}$ concentrations $(\mathrm{P}<0.05)$. This indicated that low and medium $\mathrm{O}_{3}$ stress stimulated the growth of type I methanotrophic bacteria. Under high $\mathrm{O}_{3}$ concentration ( $120 \mathrm{ppb}$ ), the 16S rRNA gene numbers of type I methanotrophic bacteria decreased significantly, especially at the depth of $10-20 \mathrm{~cm}$ (Fig. 3). The variance analysis of the experimental data indicated that the $\mathrm{O}_{3}$ concentration and soil depth significantly influenced the $16 \mathrm{~S}$ rRNA gene numbers of type I methanotrophic bacteria, especially $\mathrm{O}_{3}$ concentration had a greater influence.

The 16S rRNA gene number of type II methanotrophic bacteria in 0-10 cm layer (Fig. 3) was higher under $\mathrm{O}_{3}$ stress than the control treatment. When the $\mathrm{O}_{3}$ concentration was low (40 ppb), the gene copy number reached the maximum. The changes of the 16S rRNA gene number of type II methanotrophic bacteria under $\mathrm{O}_{3}$ stress in $10-20 \mathrm{~cm}$ layer were similar to that of the $0-10 \mathrm{~cm}$ layer. When the $\mathrm{O}_{3}$ concentration was $40 \mathrm{ppb}$, the $16 \mathrm{~S}$ rRNA gene number of type II methanotrophic bacteria of this layer reached the maximum $\left(5.56 \times 10^{7}\right.$ copies $g^{-1}$ dry soil). There was significant difference of the 16S rRNA gene number of type II methanotrophic bacteria of $10-20 \mathrm{~cm}$ layer between $\mathrm{O}_{3}$ stress and control treatment $(\mathrm{P}<0.05)$. The type II methanotrophic bacteria number in $20-40 \mathrm{~cm}$ layer was significantly lower under every $\mathrm{O}_{3}$ concentration than that of the control treatment $(\mathrm{P}<0.05)$. The variance analysis indicated that the soil depth and the $\mathrm{O}_{3}$ concentration significantly influenced the number of type II methanotrophic bacteria.

\subsection{Effects of $\mathrm{O}_{3}$ on methanotrophic abundance indicated by pmoA}

The pmoA gene numbers of the total methanotrophic bacteria in 


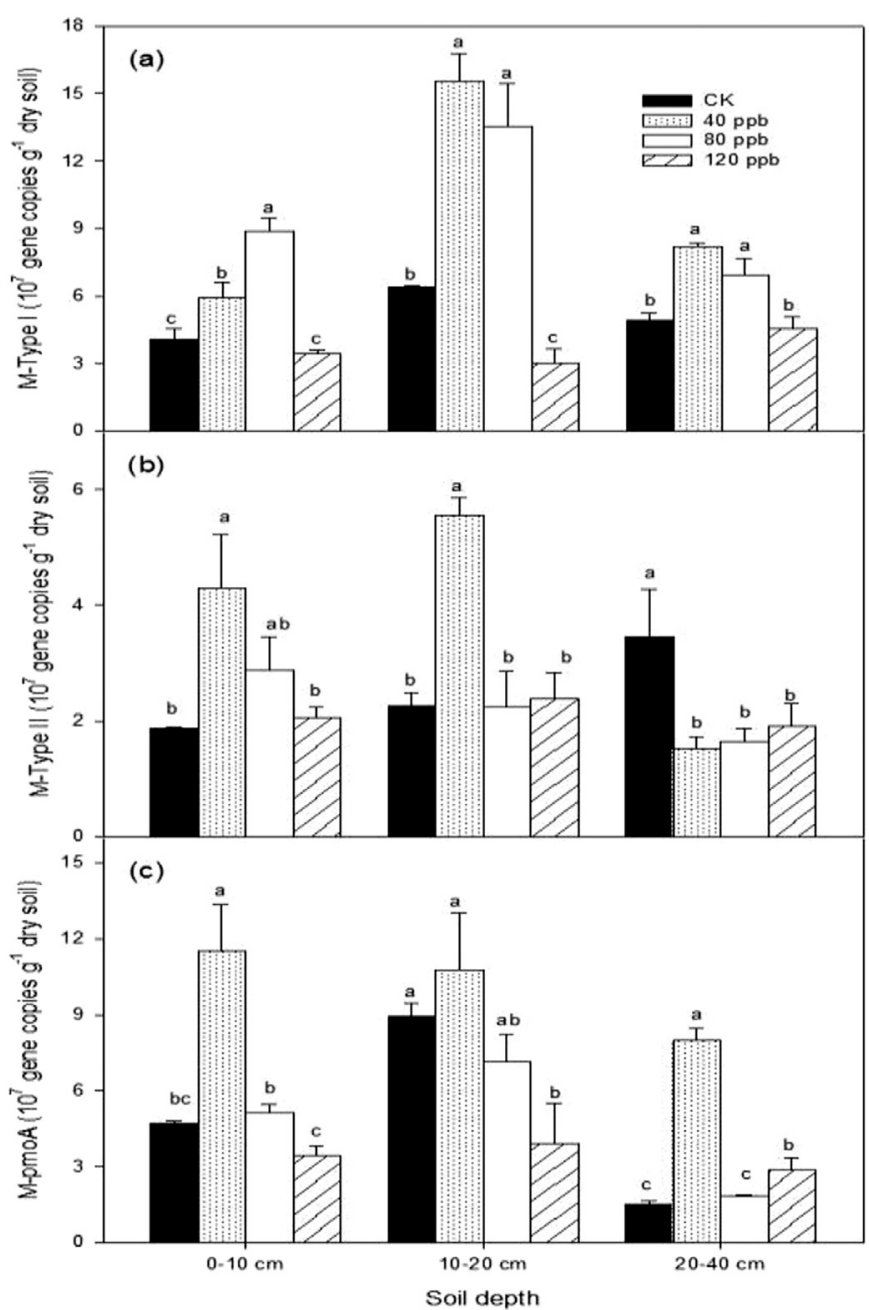

Fig. 3. Quantification of $16 S$ rRNA gene copy numbers of Type I methanotrophs (MType I: a), Type II methanotrophs (M-Type II: b) and pmoA gene copy numbers of total methanotrophs (M-pmoA: c) in winter wheat field soil under different ozone concentrations. The different letters above bars indicate significant differences between different ozone concentrations at $p<0.05$.

0-10 cm layer increased significantly under low $\mathrm{O}_{3}$ concentration (40 ppb) as compared to the control treatment $(\mathrm{P}<0.05)$; while under high $\mathrm{O}_{3}$ concentration $(120 \mathrm{ppb})$, the pmoA gene copy number decreased (Fig. 3). The $p m o A$ gene number in $10-20 \mathrm{~cm}$ layer was significantly decreased under $120 \mathrm{ppb} \mathrm{O}_{3}$ treatment as compared to the control treatment. The $p m o A$ gene copy number under this $\mathrm{O}_{3}$ concentration was only $3.89 \times 10^{7}$ copies $\mathrm{g}^{-1} \mathrm{dw}$, $56.8 \%$, lower than the control treatment. In the $20-40 \mathrm{~cm}$ layer, every $\mathrm{O}_{3}$ treatment had an increased $p m o A$ gene number. When the $\mathrm{O}_{3}$ concentration was $40 \mathrm{ppb}$, the $\mathrm{pmoA}$ gene number reached the maximum $\left(8.02 \times 10^{7}\right.$ copies $\left.\mathrm{g}^{-1} \mathrm{dw}\right)$. The variance analysis results indicated that the $\mathrm{O}_{3}$ concentration and the soil depth both had significant influence on the $p m o A$ gene number of the total methanotrophic bacteria.

Based on the $p m o A$ gene cloning and sequencing, the methanotrophic bacterial community structure was analyzed by T-RFLP. There were 8 terminal restriction fragments, 78 bp, 225bp, 243bp, $348 \mathrm{bp}, 373 \mathrm{bp}, 436 \mathrm{bp}, 445 \mathrm{bp}$ and $504 \mathrm{bp}$, in the pattern. In every sample, 78 bp, 225bp, 243bp, 348 bp, 373 bp, 436 bp fragments were detected. The sum of their relative abundances represented over $91.0 \%$ of the total methanotrophic bacteria (Fig. 4). The phylogenetic tree of $p m o A$ gene indicated that the dominant

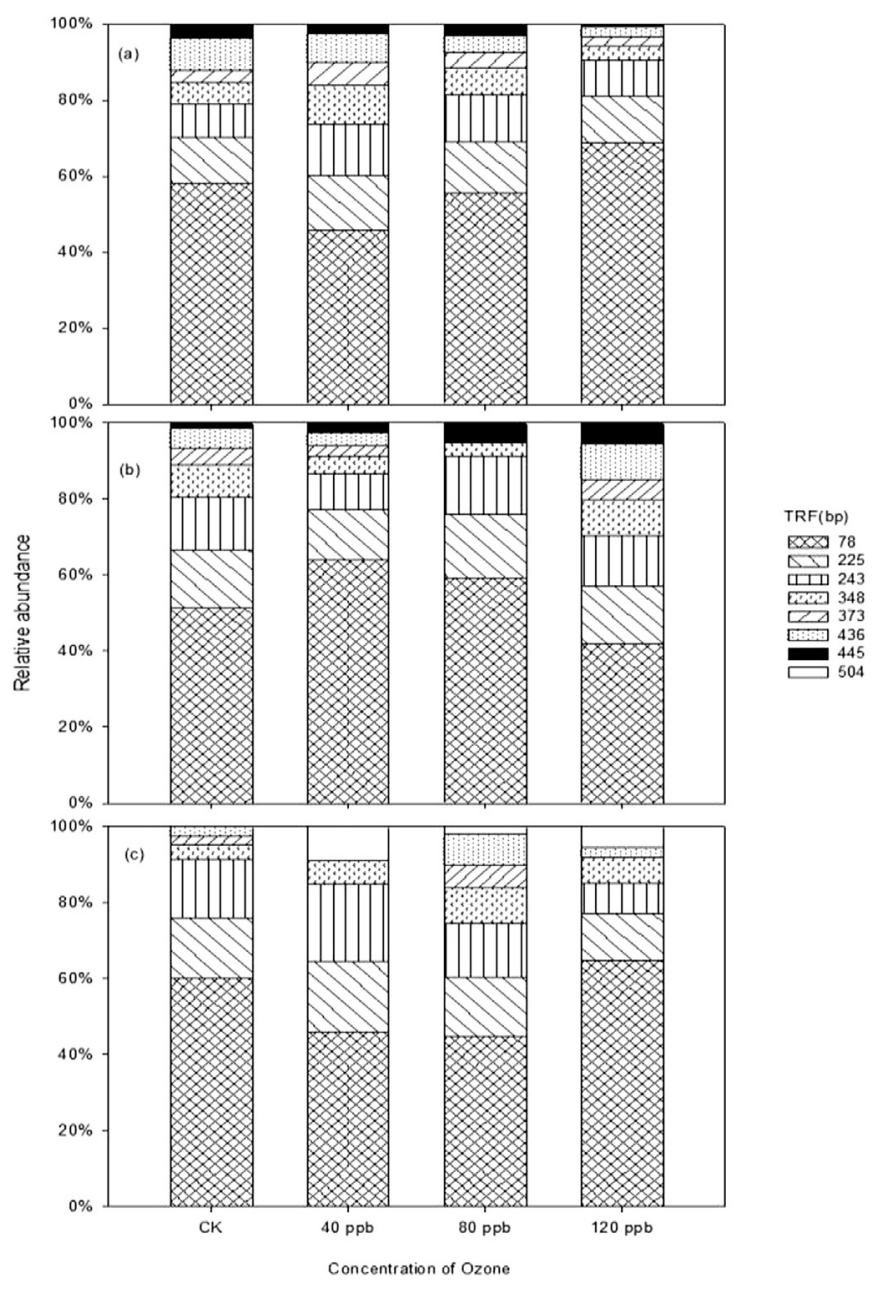

Fig. 4. Community structure of methanotrophs in winter wheat field soil under different ozone treatments, (a) 0-10 cm soil depth, (b) 10-20 cm soil depth, (c) 20-40 cm soil depth.

methanotrophic bacteria in the rhizosphere soil of winter wheat were type I and type II (Methylocystis, Methylosinus, Methylocapsa), with high diversity (Fig. 5). The analysis of the T-RFLP pattern and cloning and sequencing results indicated that only the matching sequence of T-RF 445 bps with low relative abundance was not found in the cloning library. The methanotrophic bacteria corresponding to $78 \mathrm{bp}, 225 \mathrm{bp}, 373 \mathrm{bp}, 436 \mathrm{bp}$ and $504 \mathrm{bp}$ fragments belonged to type I methanotrophic bacteria; while those of $348 \mathrm{bp}$ and $243 \mathrm{bp}$ belonged to type II.

Under different $\mathrm{O}_{3}$ treatments, the $78 \mathrm{bp}$ fragment was the most abundant, followed by 225 bp and 243 bp fragments. The structure of methanotrophic bacterial community in different soil depths showed different changes with the increasing $\mathrm{O}_{3}$ concentration. In 0-20 cm layer, methanotrophic bacteria corresponding to T-RF 504 bp were not detected; in 20-40 cm layer, T-RF 445 bp was not detected. In $0-10 \mathrm{~cm}$ layer, the relative abundance of the T-RF $78 \mathrm{bp}$ decreased when the $\mathrm{O}_{3}$ concentration was $40 \mathrm{ppb}$; then the relative abundance increased with increasing the $\mathrm{O}_{3}$ concentration. In this layer, the relative abundances of T-RF $243 \mathrm{bp}$ and $373 \mathrm{bp}$ fragments increased with the increase of $\mathrm{O}_{3}$ concentration, however those of T-RF 436 bp and 445 bp decreased.

The relative abundance of T-RF $78 \mathrm{bp}$ in the $10-20 \mathrm{~cm}$ layer reached the maximum at the $\mathrm{O}_{3}$ concentration of $40 \mathrm{ppb}$, and then decreased with the increase of $\mathrm{O}_{3}$ concentration. Its relative 


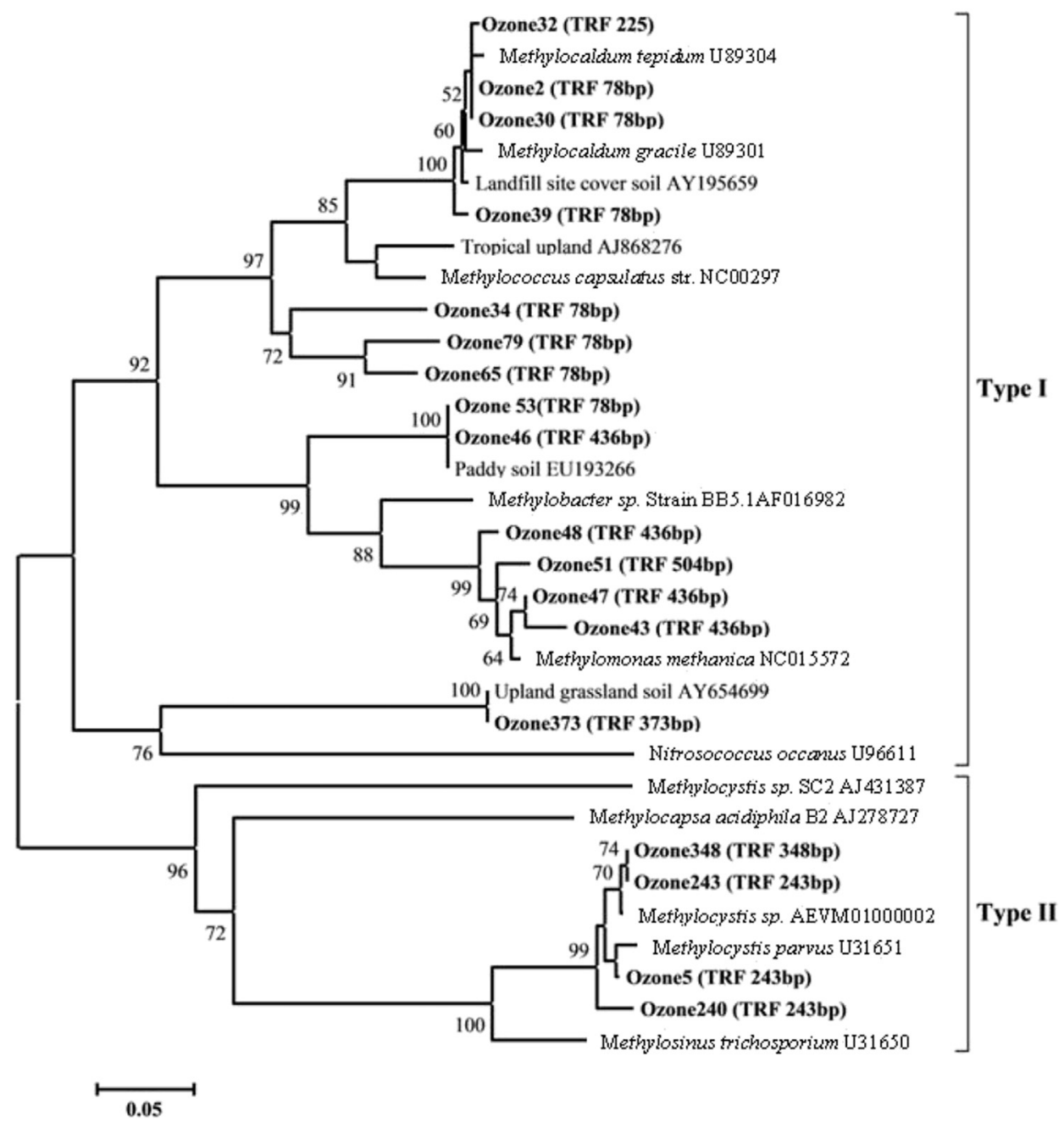

Fig. 5. Phylogenetic tree of representative $p m o A$ gene clone sequences retrieved from rhizosphere soil of winter wheat.

abundance reached the minimum when the $\mathrm{O}_{3}$ concentration was $120 \mathrm{ppb}$. In this layer, the relative abundance of T-RF $445 \mathrm{bp}$ increased with the increase of $\mathrm{O}_{3}$ concentration; while those of T$\mathrm{RF} 348 \mathrm{bp}, 436 \mathrm{bp}$ and $373 \mathrm{bp}$ decreased within the $\mathrm{O}_{3}$ concentration range of $40-80 \mathrm{ppb}$. The relative abundance of T-RF $78 \mathrm{bp}$ in the $20-40 \mathrm{~cm}$ layer was decreased under 40 and $80 \mathrm{ppb} \mathrm{O}_{3}$ concentrations, but increased under $120 \mathrm{ppb}$. In this layer, no T-RF 504 bp was detected in the $\mathrm{CK}$ treatment without $\mathrm{O}_{3}$ fumigation. Under 40-120 $\mathrm{ppb}_{3}$ stress, T-RF 504 bp was detected.

Table 2

Shannon diversity and evenness of soil methanotrophic community in $\mathrm{O}_{3}$ treatments.

\begin{tabular}{llll}
\hline Soil depths/cm & Ozone treatment & $\mathrm{H}$ & $\mathrm{E}$ \\
\hline $0-10$ & $\mathrm{CK}$ & $1.04 \pm 0.05 \mathrm{~b}$ & $0.53 \pm 0.03 \mathrm{~b}$ \\
& $40 \mathrm{ppb}$ & $1.35 \pm 0.03 \mathrm{a}$ & $0.70 \pm 0.01 \mathrm{a}$ \\
& $80 \mathrm{ppb}$ & $1.12 \pm 0.03 \mathrm{~b}$ & $0.54 \pm 0.02 \mathrm{~b}$ \\
& $120 \mathrm{ppb}$ & $0.90 \pm 0.02 \mathrm{c}$ & $0.46 \pm 0.03 \mathrm{~b}$ \\
$10-20$ & CK & $1.16 \pm 0.03 \mathrm{~b}$ & $0.60 \pm 0.02 \mathrm{~b}$ \\
& $40 \mathrm{ppb}$ & $0.95 \pm 0.05 \mathrm{c}$ & $0.49 \pm 0.02 \mathrm{c}$ \\
& $80 \mathrm{ppb}$ & $1.01 \pm 0.02 \mathrm{c}$ & $0.63 \pm 0.04 \mathrm{ab}$ \\
$20-40$ & $120 \mathrm{ppb}$ & $1.52 \pm 0.06 \mathrm{a}$ & $0.73 \pm 0.03 \mathrm{a}$ \\
& CK & $1.14 \pm 0.04 \mathrm{~b}$ & $0.64 \pm 0.04 \mathrm{a}$ \\
& $40 \mathrm{ppb}$ & $1.13 \pm 0.03 \mathrm{~b}$ & $0.70 \pm 0.03 \mathrm{a}$ \\
& $80 \mathrm{ppb}$ & $1.36 \pm 0.06 \mathrm{a}$ & $0.70 \pm 0.03 \mathrm{a}$ \\
& $120 \mathrm{ppb}$ & $0.88 \pm 0.03 \mathrm{c}$ & $0.49 \pm 0.02 \mathrm{~b}$ \\
\hline
\end{tabular}

The diversity index is a comprehensive measure of the abundance and the evenness. The Shannon index $(\mathrm{H})$ and the evenness index (E) of the methanotrophic bacteria are shown in Table 2. It can be seen that the soil depth had greater impact on the diversity index and evenness index. The $\mathrm{H}$ and $\mathrm{E}$ values in the $0-10 \mathrm{~cm}$ layer reached the maximum when $\mathrm{O}_{3}$ concentration was $40 \mathrm{ppb}$. The $\mathrm{H}$ and $\mathrm{E}$ values in the $10-20 \mathrm{~cm}$ layer reached the maximum when $\mathrm{O}_{3}$ concentration was $120 \mathrm{ppb}$. The $\mathrm{H}$ and $\mathrm{E}$ values in the $20-40 \mathrm{~cm}$ layer reached the maximum when $\mathrm{O}_{3}$ concentration was $80 \mathrm{ppb}$ and the minimum when $\mathrm{O}_{3}$ concentration was $120 \mathrm{ppb}$. In the $10-20 \mathrm{~cm}$ and $20-40 \mathrm{~cm}$ layers, the E values of the methanotrophic bacteria were in significant correlation with the $\mathrm{O}_{3}$ concentration. The correlation coefficients $r$ were 0.693 and -0.587 , respectively $(\mathrm{n}=12, \mathrm{p}<0.05)$.

\section{Discussion}

\subsection{The influence of $\mathrm{O}_{3}$ concentration increase on PMOR and PMPR}

Potential methane production rate (PMOR) is the comprehensive phenomenal characteristic of the methanotrophic bacterial communities, methane-oxidizing activity and their influential factors. The comprehensive research on PMOR and soil methanotrophic bacterial community could help understand the influencing mechanism of the rising $\mathrm{O}_{3}$ concentration on the methane cycling 
from the biological perspective. This study indicated that under $\mathrm{O}_{3}$ treatments, PMOR in $0-20 \mathrm{~cm}$ layer was lower than that of CK treatment, while in the $20-40 \mathrm{~cm}$ layer, the difference was not significant. The analysis of PMOR and $\mathrm{O}_{3}$ AOT40 (accumulated exposure over a threshold of $40 \mathrm{ppb}$ ) values showed negative correlation between the two indicators $(\mathrm{r}=-0.493, \mathrm{p}<0.01, \mathrm{n}=36)$. As it is hard for $\mathrm{O}_{3}$ to penetrate the soil, its influence on soil methane oxidation is indirect (McCool and Menge, 1983). The increase of $\mathrm{O}_{3}$ concentration will disturbs the photosynthesis of plants, causing the drop of plant biomass and changing the distribution of the root exudates (McCool and Menge, 1983). Thus, the content of mineral elements and organic elements may change, resulting in the change of soil methanotrophic bacterial activity and PMOR. The correlation analysis between soil PMOR and PMPR indicated negative correlation $(\mathrm{r}=-0.288, \mathrm{p}<0.05, \mathrm{n}=36)$. This showed that the soil methane-oxidizing process and the methane production process are mutually interfering. In this research, the pmoA gene number of soil total methanotrophic bacteria, the numbers of type I and type II methanotrophic bacteria were not in significant correlation with PMOR, indicating that PMOR is not determined by the number of methanotrophic bacteria.

PMPR is generally associated with the activity of soil methanotrophic bacteria (Yavitt et al., 1988). The research on the influence of different $\mathrm{O}_{3}$ concentrations on the PMPR of winter wheat field soil indicated that the soil PMPR increased as at deeper depth without $\mathrm{O}_{3}$ fumigation. After the increase of $\mathrm{O}_{3}$ concentration, this tendency was not observed. The rising $\mathrm{O}_{3}$ concentration would cause the change of the soil microbial biomass carbon (Sinsabaugh et al., 2002), plant roots (Renaud et al., 1997), soil respiration (Edwards, 1991) and soil temperature (Mosier, 1998), therefore affecting the activity of soil methanogens. In this research, $\mathrm{O}_{3}$ increased PMPR at 0-20 cm layer of wheat soil. With the deepening of the soil depth, especially in the 20-40 cm layer, PMPR decreased as the $\mathrm{O}_{3}$ concentration increased. This might be related to the influence of $\mathrm{O}_{3}$ stress on plant root growth and root exudates (Renaud et al., 1997). Some researches have found that the $\mathrm{O}_{3}$ stress could significantly lower the methane emission in farmland soil (Bhatia et al., 2011; Zheng et al., 2011). Its mechanism can be explained by the influence of $\mathrm{O}_{3}$ stress on soil PMOR, PMPR and soil microbial activity.

\subsection{Influence of $\mathrm{O}_{3}$ on the abundance of methanotrophic bacteria}

In the $\mathrm{CK}$ treatment without $\mathrm{O}_{3}$ fumigation, the pmoA gene copy number in the $10-20 \mathrm{~cm}$ layer was much higher than that in the other two layers. The low concentration $(40 \mathrm{ppb})$ of $\mathrm{O}_{3}$ could significantly increase the $p m o A$ gene copy number of methanotrophic bacteria and the $16 \mathrm{~S}$ rRNA gene number of type I and type II methanotrophic bacteria in the $0-20 \mathrm{~cm}$ layer. Under high concentration $(120 \mathrm{ppb})$, the three gene numbers were significantly lower than those of the $\mathrm{CK}$ treatment. The correlation analysis between $\mathrm{O}_{3}$ AOT40 value and the abundance of methanotrophic bacteria indicated that the $\mathrm{O}_{3}$ concentration showed significantly negative correlations with $p m o A$ gene number $(r=-0.396$, $\mathrm{p}<0.01, \mathrm{n}=36$ ), and the 16s rRNA gene numbers of type I $(\mathrm{r}=-0.422, \mathrm{p}<0.01, \mathrm{n}=36)$ and type II $(\mathrm{r}=-0.379, \mathrm{p}<0.01$, $\mathrm{n}=36$ ). Thus, the rise of $\mathrm{O}_{3}$ concentration had an inhibitory effect on the growth and proliferation of methanotrophic bacteria. The possible reasons are (1) $\mathrm{CH}_{4}$ oxidation involves the aerobic microbes. The sufficient supply of $\mathrm{O}_{2}$ is important to the growth of methanotrophic bacteria and $\mathrm{CH}_{4}$ oxidation. Elevated $\mathrm{O}_{3}$ concentration would lead to the rise of $\mathrm{CO}_{2}$ production and $\mathrm{O}_{2}$ consumption of plants (Scagel and Andersen, 1997). Thus, the abundance of the soil methanotrophic bacteria would decrease (McLain et al., 2002). (2) The ammonia oxidizing bacteria and the methanotrophic bacteria in the soil shared several common substrates
(Holmes and Costello, 1995). The rise of $\mathrm{O}_{3}$ concentration could cause the decrease of soil ammonium nitrogen and nitrate nitrogen (Li et al., 2010). The ammonium oxidizing bacteria and the methanotrophic bacteria compete for the substrates such as nitrogen (Bedard and Krause, 2007), causing the decrease of the abundance of methanotrophic bacteria.

In this research, the 16S rRNA gene numbers of type I and type II methanotrophic bacteria were in significant positive correlation with $p m o A$ gene copy number, indicating that the quantification results of the 16S rRNA gene of methanotrophic bacteria was basically consistent with those of the pmoA gene. In all treatments, the number of type I bacteria was significantly higher than that of Type II. The methane oxidizing process is as follows (Hanson and Hanson, 1996; Madigan et al., 2009): first, methane is oxidized to methanol by type I methanotrophic bacteria under the action of soluble methane monooxygenase (sMMO), or by type II bacteria under the action of particulate methane monooxygenase (pMMO) and sMMO; then, methanol is oxidized to formaldehyde and $\mathrm{CO}_{2}$ by type I bacteria via ribulose monophosphate pathway (RuMP) or by type II bacteria via the serine pathway. The RuMP of type I methanotrophic bacteria is more efficient than that of the serine pathway of type II bacteria. This could be one of the reasons for the higher number of type I bacteria than type II in winter wheat field soil.

\subsection{Influence of $\mathrm{O}_{3}$ on the structure and diversity of methanotrophic bacterial community}

The T-RFLP analysis of the $p m o A$ gene of methanotrophic bacteria indicated that the relative abundance of type I was higher than that of type II. This was coherent to the quantitative PCR results of $16 \mathrm{~S}$ rRNA gene of methanotrophic bacteria. The T-RFLP analysis on pmoA gene and the phylogenetic tree results indicated that the diversity of type I bacteria was significantly higher than that of Type II bacteria. This conformed to the results of many previous studies (Henckel et al., 2000; Eller and Frenzel, 2001). This research found that no T-RF 504 bp was detected in the 0-20 layer, but fragment TRF 445 bp was detected. This phenomenon was not observed in the 20-40 layer. The methanotrophic bacterial population corresponding to T-RF $504 \mathrm{bp}$ is phylogenetically closer to Methylomonas methanica (G-) (Fig. 5). Bacteria of this type are widely found in the sediments of lakes, water and rivers, as well as swamps (Yun et al., 2013).

The Shannon index $(\mathrm{H})$ and the evenness index $(\mathrm{E})$ are both used to represent the diversity of the soil microbial community. In this research, the $\mathrm{O}_{3}$ concentration and soil depth were found to influence the $\mathrm{H}$ and $\mathrm{E}$ values of the soil methanotrophic bacterial community. Especially, the E values in the $10-20 \mathrm{~cm}$ and $20-40 \mathrm{~cm}$ layers were in significant correlation with $\mathrm{O}_{3}$ concentration. This indicated that the rise of $\mathrm{O}_{3}$ concentration could influence the diversity and evenness of soil methanotrophic bacteria.

In conclusion, $\mathrm{O}_{3}$ stress could influence the gene copy number of total methanotrophic bacteria $p m o A, 16 \mathrm{~S}$ rRNA gene numbers of type I and type 2 methanotrophic bacteria at different depths of winter wheat field soil. Thus, the structure and diversity of soil methanotrophic bacterial community are further affected. The high concentration of $\mathrm{O}_{3}$ inhibits the growth and proliferation of soil methanotrophic bacteria. The rise of $\mathrm{O}_{3}$ concentration would cause the changes of PMOR and PMPR, thereby indirectly influencing the carbon cycling and methane emission in the field soil.

\section{Acknowledgments}

This work was supported by the National Natural Science Foundation of China (No. 41071336), Science and Technology 
Innovation Project of Chinese Academy of Agricultural Sciences.

\section{References}

Avnery, S., Mauzerall, D.L., Fiore, A.M., 2013. Increasing global agricultural production by reducing ozone damages via methane emission controls and ozone resistant cultivar selection. Glob. Change Biol. 19, 1285-1299.

Bedard, K., Krause, K.H., 2007. The NOx family of ROS-generating NADPH oxidases: physiology and pathophysiology. Physiol. Rev. 87, 245-313.

Bhatia, A., Ghosh, A., Kumar, V., Tomer, R., Singh, S.D., Pathak, H., 2011. Effect of elevated tropospheric ozone on methane and nitrous oxide emission from rice soil in north India. Agric. Ecosyst. Environ. 144, 21-28.

Bodelier, P.L.E., Roslev, P., Henckel, T., Frenzel, P., 2000. Stimulation by ammoniumbased fertilizers of methane oxidation in soil around rice roots. Nature 403, 421-424.

Bodrossy, L., Holmes, E.M., Holmes, A.J., 1997. Analysis of 16S rRNA and methane monooxygenase gene sequences reveals a novel group of thermotolerant and thermophilic methanotrophs, Methylocaldum gen. nov. Arch. Microbiol. 168, 493-503.

Chen, Z., Wang, X.K., Feng, Z.Z., 2009. Impact of elevated $\mathrm{O}_{3}$ on soil microbial community function under wheat crop. Water Air Soil Pollut. 198, 189-198.

Duxbury, J.M., Mosier, A.R., 1993. Status and issues concerning agricultural emissions of greenhouse gases. In: Kaiser, H.M., Drennen, T.E. (Eds.), Agricultural Dimensions of Global Climate Change. St Lucie Press, Delray Beach, Florida, USA, pp. 229-258.

Edwards, C., Hales, B., Hall, G., 1998. Microbiological processes in the terrestrial carbon cycle: methane cycling in peat. Atmos. Environ. 32, 3247-3255.

Eller, G., Frenzel, P., 2001. Changes in activity and community structure of methaneoxidizing bacteria over the growth period of rice. Appl. Environ. Microbiol. 67, 2395-2403.

Edwards, N.T., 1991. Root and soil respiration responses to ozone in Pinus taeda L. seedlings. New Phytol. 118, 315-321.

Feng, Z.W., Jin, M.H., Zhang, F.Z., Huang, Y.Z., 2003. Effects of ground-level ozone $\left(\mathrm{O}_{3}\right)$ pollution on the yields of rice and winter wheat in the Yangtze River delta. J. Environ. Sci. 15, 360-362.

Fiscus, E.L., Booker, F.L., Burkey, K.O., 2005. Crop responses to ozone: uptake, modes of action, carbon assimilation and partitioning. Plant Cell Environ. 28, 997-1011.

Hanson, R.S., Hanson, T.E., 1996. Methanotrophic bacteria. Microbiol. Mol. Biol. Rev. 6, 439-471.

Henckel, T., Friedrich, M., Conrad, R., 1999. Molecular analyses of the methaneoxidizing microbial community in rice field soil by targeting the genes of the 16S rRNA, particulate methane monooxygenase, and methanol dehydrogenase. Appl. Environ. Microbiol. 65, 1980-1990.

Henckel, T., Roslev, P., Conrad, R., 2000. Effects of $\mathrm{O}_{2}$ and $\mathrm{CH}_{4}$ on presence and activity of the indigenous methanotrophic community in rice field soil. Environ. Microbiol. 2, 666-679.

Holmes, A.J., Costello, A., 1995. Evidence that particulate methane monooxygenase and ammonia monooxygenase may be evolutionarily related. FEMS Microbiol. Lett. 132, 203-208.

Huang, Y.Z., Sui, L.H., Wang, W., 2012. Visible injury and nitrogen metabolism of rice leaves under ozone stress, and effect on sugar and protein contents in grain. Atmos. Environ. 62, 433-440.

Islam, K.R., Mulchi, C.L., Ali, A.A., 2000. Interactions of tropospheric $\mathrm{CO}_{2}$ and $\mathrm{O}_{3}$ enrichments and moisture variations on microbial biomass and respiration in soil. Glob. Change Biol. 6, 255-265.

Kasurinen, A., Keinanen, M.M., Kaipainen, S., 2005. Belowground responses of silver birch trees exposed to elevated $\mathrm{CO}_{2}$ and $\mathrm{O}_{3}$ levels during three growing seasons. Glob. Change Biol. 11, 1167-1179.

Knief, C., Kolb, S., Bodelier, P.L.E., Lipski, A., Dunfield, P.F., 2006. The active methanotrophic community in hydromorphic soils changes in response to changing methane concentration. Environ. Microbiol. 8, 321-333.

Le Mer, J., Roger, P., 2001. Production, oxidation, emission and consumption of methane by soils: a review. Eur. J. Soil Biol. 37, 25-50.

Li, Q.S., Lin, X.G. Hu, J.L., 2010. Effects of elevated $\mathrm{O}_{3}$ concentration in surface laye on activity of soil ammonia-oxidizing bacteria and denitrifying bacteria in wheat field. J. Ecol. Rural Environ. 26, 524-528.

Madigan, M.T., Martinko, J.M., Dunlap, P.V., 2009. Brock Biology of Microorganisms, twelfth ed. Pearson Benjamin-Cummings, San Francisco.

McCool, P., Menge, J., 1983. Influence of ozone on carbon partitioning in tomato: potential role of carbon flow in regulation of the mycorrhizal symbiosis under conditions of stress. New Phytol. 94, 241-247.

McDonald, I.R., Hall, G.H., Pickup, R.W., Murrell, J.C., 1996. Methane oxidation potential and preliminary analysis of methanotrophs in blanket bog peat using molecular ecology techniques. FEMS Microbiol. Ecol. 21, 197-211.

McLain, J.E.T., Kepler, T.B., Ahmann, D.M., 2002. Belowground factors mediating changes in methane consumption in a forest soil under elevated $\mathrm{CO}_{2}$. Glob Biogeochem. Cycles 16, 1-14.

Mosier, A., 1998. Soil processes and global change. Biol. Fertil. Soils 27, 221-229.

Raghoebarsing, A.A., Smolders, A.J.P., Schmid, M.C., Rijpstra, W.I.C., Wolters-Arts, M. Derksen, J., Jetten, M.S.M., 2005. Methanotrophic symbionts provide carbon for photosynthesis in peat bogs. Nature 436, 1153-1156.

Reddy, G., Reinert, R., Eason, G., 1995. Loblolly pine needle nutrient and soil enzyme activity as influenced by ozone and acid rain chemistry. Soil Biol. Biochem. 27, 1059-1064.

Renaud, J., Allard, G., Mauffette, Y., 1997. Effects of ozone on yield, growth, and root starch concentrations of two alfalfa (Medicago sativ A L.) cultivars. Environ. Pollut. 95, 273-281.

Scagel, C.F., Andersen, C.P., 1997. Seasonal changes in root and soil respiration of ozone-exposed ponderosa pine (Pinus ponderosa) grown in different substrates. New Phytol. 136, 627-643.

Selin, N.E., Wu, S., Nam, K.M., Reilly, J.M., Paltsev, S., Prinn, R.G., Webster, M.D., 2009. Global health and economic impacts of future ozone pollution. Environ. Res. Lett. 4, 1-9.

Shao, M., Tang, X., Zhang, Y., 2006. City clusters in China: air and surface water pollution. Front. Ecol. Environ. 4, 353-361.

Shindell, D.T, Faluvegi, G., Koch, D.M., Schmidt, G.A., Unger, N., Bauer, S.E., 2009. Improved attribution of climate forcing to emissions. Science 326, 716-718.

Sinsabaugh, R.L., Larson, J.L., Zak, D.R., 2002. Extracellular enzyme activity beneath temperate trees growing under elevated carbon dioxide and ozone. Soil Sci. Soc. Am. J. 66, 1848-1856.

Sitch, S., Cox, P.M., Collins, W.J., Huntingford, C., 2007. Indirect radiative forcing of climate change through ozone effects on the land-carbon sink. Nature 448 , $791-794$.

Thompson, A.M., Hogan, K.B., Hoffman, J.S., 1992. Methane reductions-implications for global warming and atmospheric chemical change. Atmos. Environ. 26 2665-2668.

Wang, S.Y., Han, L., Shi, Y., 2007. Effects of FACE on population and activities of methanogen and methanotroph in paddy soil. Soils 38, 768-773.

Yavitt, J.B., Lang, G.E., Downey, D.M., 1988. Potential methane production and methane oxidation rates in peatland ecosystems of the Appalachian Mountains, United States. Glob. Biogeochem. Cycles 2, 253-268.

Yun, J.L., Wang, Y.F., Zhang, H.X., 2013. Ecology of aerobic methane oxidizing bacteria (methanotrophs). Acta Ecol. Sin. 33, 6774-6785 (in Chinese)

Zhang, W.F., 2010. Study on the Variation and Predietion Method of Ozone Concentration in Beijing Urban Area. Beijing Forestry University. Master Thesis (in Chinese).

Zheng, F.X., Wang, X.K., Lu, F., 2011. Effects of elevated ozone concentration on methane emission from a rice paddy in Yangtze River Delta, China. Glob. Change Biol. 17, 898-910.

Zheng, Y., 2009. Molecular Ecological Characteristics of Methanotrophs in Chinese Paddy and Upland Red Soils. PhD thesis. Research Center for Eco-Environmental Sciences, Chinese Academy of Sciences (in Chinese).

Zhu, X.K., Feng, Z.Z., Sun, T.F., Liu, X.C., Tang, H.Y., Zhu, J.G., Guo, W.S., Kobayashi, K. 2011. Effects of elevated ozone concentration on yield of four Chinese cultivars of winter wheat under fully open-air field conditions. Glob. Change Biol. 17, 2697-2706. 